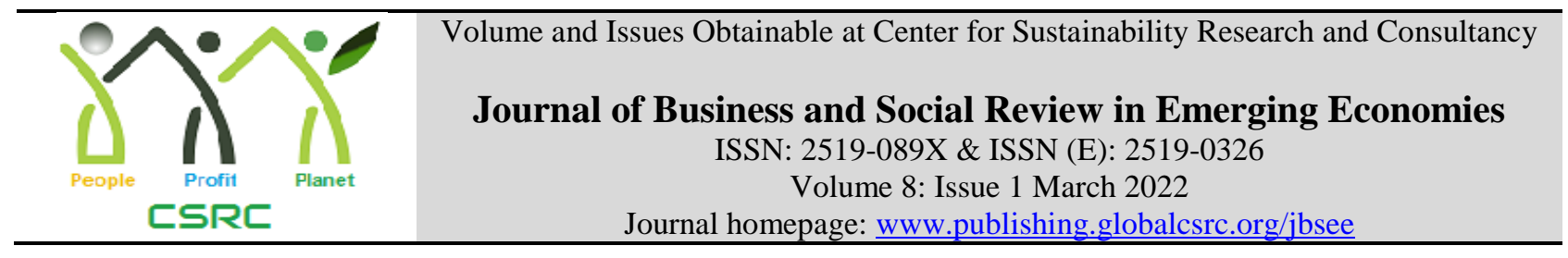

\title{
Criteria for the Selection of Suppliers: A Case of Motorcycle Industry of Pakistan
}

*Zara Hayat, Bahauddin Zakariya University, Multan, Pakistan

Sahar Hayat, NFC-IET, Multan, Pakistan

Sohail Aslam, Islamia University, Bahawalpur, Pakistan

Hayat Muhammad Awan, Insititute of Southern Punjab, Pakistan

*Corresponding author's email: prorector@isp.edu.pk

\begin{tabular}{l}
\hline ARTICLEDETAILS \\
\hline History \\
Revised format: Feb 2022 \\
Available Online: Mar 2022 \\
\hline Keywords \\
Suppliers, Motorcycle \\
industry, Pakistan, Quality, \\
Manufacturing
\end{tabular}

JEL Classification

L6, L62

\section{OPEN ACCESS}

\section{ABSTRACT}

Purpose: Supplier selection is receiving considerable attention these days; firms are investing heavily in finding those suppliers who can give them better quality products in lowest possible cost. This paper reveals the appropriate supplier selection criteria in motorcycle industry of Pakistan and this paper also reveals whether this selection differ in different regions or it is uniform in its nature.

Methodology: For this we have adopted a questionnaire from Supplier Selection Instrument and make it filled from Purchase managers of 24 different companies from different locations. Non probability sampling technique was used. Specifically quota sampling was used to make sure sample is equally represented across region then factor analysis was run to see which items were appropriate in Pakistani settings.

Findings: Result shows that companies prefer those suppliers who are offering better service and quality features to the manufacturing companies. And supplier selection in Lahore and Karachi is similar but supplier selections in other regions of Punjab are different.

Implications: Companies should consider those suppliers, having strategic importance to their firm so they should built consensus between the company and the supplier that every decision will be made through mutual collaboration. Companies should make relationship with their suppliers and try to make transparency in business transactions.

(C2021The authors, under a Creative Commons AttributionNonCommercial 4.0

Recommended citation: Hayat, Z., Hayat, S., Aslam, S. and Awan, H. M. (2022). Criteria for the Selection of Suppliers: A Case of Motorcycle Industry of Pakistan. Journal of Business and Social Review in Emerging Economies, 8(1), 1-12. 


\section{Introduction}

\section{Motorcycle industry of Pakistan}

In many places of the world, the motorcycle is the primary mode of private transportation. However, because of its magnitude and difficult operations, engineers and planners frequently overlook it while planning and managing metropolitan streets. China's rise as a significant player in the global motorcycle industry has been fueled by a combination of strong domestic demand and a plethora of low-tech manufacturing or cloning.

Pakistan is the only country where the government does not conduct follow-up severe quality checks on products after they leave manufacturers for the markets, and some low-cost Chinese cumin seeds are sold there. Pakistani bikes are included in this category as well.

There are currently only three Chinese cum Pakistani bikes, which sell well due to their brand name, are still being produced in small quantities by the majority of assemblers in order to stay in business. They have invested millions of rupees in motorbike assembly projects, and if they close their firm, they will lose a significant amount of money in the form of factory investment. Many businesses have closed their doors after failing to survive due to poor quality and exorbitant production costs.

The prices of Chinese bikes, on the other hand, have not been raised in the same way that the prices of Japanese bikes have been raised in response to the rupee's depreciation against various currencies. Consumers in various parts of the country appear to be satisfied with the low-cost, high-quality motorcycles offered by various manufacturers.

In Pakistan, a product is usually launched without much thought, but the producers ignore aftersales service and quality issues despite high volume sales. The rise in Chinese bike sales does not indicate that the quality of the bikes has improved; rather, the low price of the Chinese bikes compared to the Japanese Honda 70cc is the primary factor. Chinese bikes are not popular in rural areas because many companies do not provide after-sales service throughout Pakistan, and they are also inferior in terms of quality and durability to Japanese bikes. Growers typically buy expensive Japanese bikes before and after harvesting good crops, but they have less faith in Chinese bikes because they need tough bikes to run on the crumbling roads and passages in rural and crop-producing areas.

In the year 2001, there were only six motorcycle assemblers in Pakistan. Three were Japanese (Honda, Yamaha, and Suzuki) and rest Chinese (Sohrab, Qingqi, and Hero. Many motorcycle dealers including Babar Autos, Sitara Auto Impex, Moon Traders from Karachi and Lahore were compelled to import CBU motorcycles from China on the prevalent rate. Many of them also started assembling with local brand names such as:-Rocket, Guanta Star, Jinan and Super Star.

However manufacturers and assemblers of motorcycles have to purchase the components and subassemblies from suppliers from foreign countries or within Pakistan, These companies were not caring the selection criteria of suppliers. Therefore in this paper we explore the selection criteria of suppliers.

\section{Literature Review}

\section{Impact of Supplier Quality in Supplier Selection}

It is now a very common practice in almost every organization to produce high quality products in lowest possible cost to achieve maximum return on their investment so selecting a supplier who provide them high quality product in lowest possible cost is very important. It's not only to reduce their cost but it is also very important to sustain in the competitive business environment. Companies who are producing their products in low cost they will introduce their ready product in low price in contrast if other organization are not doing this practice they will produce their 
product in high cost will launch their ready product in high price so they will be automatically out of the market.

It is quite difficult to produce high quality products in lowest possible cost so firms usually relies on those supplier who provide them desired products in lowest possible cost, low cost is not the only criteria for a firm to choose a supplier there are so many other things which are also very important in supplier selection for example quality of a supplier is also depend on the testing capability from which we mean innovative production processes. Firms who are famous in offering innovative products in the market are not price conscious and in the selected industry for this research automobile industry is very innovative in nature. Companies who are introducing new models of cars, bikes and trucks are having competitive advantage on other companies.

Increasingly, firms are allocating more resources to their core competencies and encouraging the outsourcing of non-core activities, which increases their reliance and dependence on suppliers. (Vijay and Tan, 2006). It is very common practice in the automobile industry of Pakistan that they usually select supplier from other parts of the world who are having expertise in those fields for example Pak Hero motorcycles were a Pakistani brand but they have imported each and every part of the bike from china and just assembled them in their warehouses.

Gurler (2006) founded some very important points regarding suppler selection. According to him, in Turkish automotive industry the most important supplier selection factor is adequacy of corporate. This factor consisted of technical expertise level, references reputation of supplier, financial stability and staying power, ability to meet delivery due dates, ability to have honest and frequent communications with suppliers.

Sonemz (2006) determined that public sector organizations usually concentrate on price related issues while selecting the supplier but as far as private sector organization are concerned they usually were more focused on quality, time delivery, buyer seller long term relationship and after sale services. Peter (2007) suggested some very important aspects in creating a better supply chain. He focused on using relationship management approach for long term value from customers and then it would transform into higher levels of commitment, loyalty and satisfaction. Vijay and Tan (2004) suggested companies prefer to concentrate on their core activities and not on non-core activities so that is why they tend to rely more on their suppliers for non-core activities and effective supplier selection is very important.

The vendor selection process has undergone significant changes during the past twenty years. These include increased quality guidelines, improved computer communications, and increased technical capabilities. Seungwook et al (2001) investigated Quality management practices and their relationship to buyer's supplier ratings in Korean automotive industry and determined that process management can have a multifaceted effect by improving quality, delivery, and cost performance.

\section{Impact of Service Quality on Supplier Selection}

Supplier service is another very important criteria in selecting a supplier, it is very important to serve the customer at timely manner (Delivery due dates) and should respond quickly to unexpected demand. Service is an essential factor in supplier selection process in all multinational and national companies which are striving to better their services to compete in competitive markets. If a company is giving better services than their competitors, then they have better chances to expand their market share. Especially in automobile sector, if any company compromise on the services it will definitely lose its market share and position.

Kannan and Tan (2003) investigated attitudes of US and European managers to supplier selection 
and assessment and implications for business performance and determined that European and American market are very similar in selecting a supplier. While selecting a supplier they try to make strategic alliance with their supplier and tie some strong relationships, they not treat them as a separate entity but they treat them as their own important part.

Kannan and Tan (2006) studied the Buyer supplier Relationship and established that positive relationship should be made with supplier and try to select that supplier who can give you long term benefits instead of making relationships on short term basis.

Julie (2006) studied Carrier involvement in buyer-supplier strategic partnerships and found out that companies are making strategic alliance and partnerships in order to secure good services. Dona Gill (2006) studied Influences on supplier repurchase selection of UK importers and found out that while purchasing goods from the supplier the things which really matters are product quality and payment facility. Sarkis and Talluri (2004) worked on Model for Strategic Supplier Selection and suggested that purchasing is becoming a very important and essential factor in supply chain management as purchasing reduce the cost of manufacturing and increase the profitability of the firm. Aissaoui et al (2006) determined that managers gave deep attention to purchasing and considered it as a key strategic tool to gain competitive advantage.

Das and Malek (2004) studied the flexibility of order quantities and lead-times in supply chains and determined that a good supply chain is that where buyers and supplier accommodate the uncertainties and variations in each other's businesses

\section{Impact of Supplier Strategy Management Fit in Supplier Selection}

Companies now days are heavily dependent on the supplier to run their business smoothly and to get sustainable competitive advantage. So there is a great deal of effort and greater need of alignment between buyer and supplier. So facet of supplier selection is to evaluate whether that strategic goals and management objectives match with their buyers and suppliers or not. For the purpose of this research, strategic fit is defined in terms of tendency of the buyer and supplier to act in a unified manner towards a desired strategic goal. The supplier selection literature has tended to focus more on tangible, measurable criteria, and intangible criteria of strategic/management fit.

Within the purchasing function, one of the prime responsibilities is the evaluation and selection of suppliers. In today's highly competitive, global operating environment, it is impossible to produce low cost, high quality products successfully without satisfactory suppliers. The selection of suppliers is one of most important functions of purchasing. This decision is even more important now with strategic partnerships being formed with suppliers for competitive advantage and the reduction of supplier biases.

Kannan and Tan (2004) studied supplier alliances and differences in attitudes to supplier and quality management of adopters and non-adopters. He established that recently strategic alliance between supplier and buyer is very important in this competitive environment.

\section{Methodology}

Three criteria were identified based on the literature review: Supplier Quality, Supplier Service, and Strategic Management Fit; however, the factors drawn on the basis of "supplier selection instrument and construct" supported (Kannan and Tan, 2003). Supplier quality has long been cited as a significant consideration for selecting suppliers (Kannan and Tan, 2003). Furthermore, it has long been seen as a crucial component in the development of strategic buyer-supplier relationships. The relevance of a supplier's ability to match buyer needs was also highlighted in the supplier selection research. This has two sides to it. First and foremost, suppliers must be able 
to meet consumer demand in a timely way and adapt quickly to demand fluctuations. Not only does the literature on supplier selection emphasize the importance of delivery service (Kannan and Tan, 2003), but also the literature on supply chain management and time-based competition emphasize the importance of supplier responsiveness to changing buyer needs, especially in an environment marked by short product life cycles and downward pressure on product lead.

Second, the provider should be able to do it in a way that is consistent with the buyer's price expectations. This is in line with empirical findings suggesting that the cost of materials and services is a critical consideration when choosing suppliers (Kannan and Tan, 2006). Firms are more reliant on suppliers than ever before, and material flows are increasingly managed from a supply chain viewpoint. These variables indicate that there is a larger need for stronger alignment between the buyer and the supplier, particularly in terms of strategic/management fit. This aspect of supplier selection looks at whether the buyers and supplier's strategic goals and management philosophies are in sync. For the purposes of this study, strategic fit is defined as whether the buyer and supplier work together to achieve a common strategic aim. Management fit is measured by whether each entity tries to comprehend the other's aims and goals, as well as understanding the situation from the other's point of view.

Lastly we are interested in finding out supplier selection criteria with respect to different companies and localities of purchasing agents. The measurements of items of suppliers selection is based on the suppliers selection instrument ((CHAN \& CHAN 2004 and Chin-Chun; 2005 and Julie 2005).

The research framework Fig. 1 is generated on the basis of this discussion. In the theoretical framework, three constructs of supplier selection- quality of suppliers, supplier service and strategic fit are measured on the basis of 5-point likert scale- strongly agree to strongly disagree. 24 suppliers from 5 cities of Pakistan are selected on the basis of recommendation of manufacturers on quota basis.

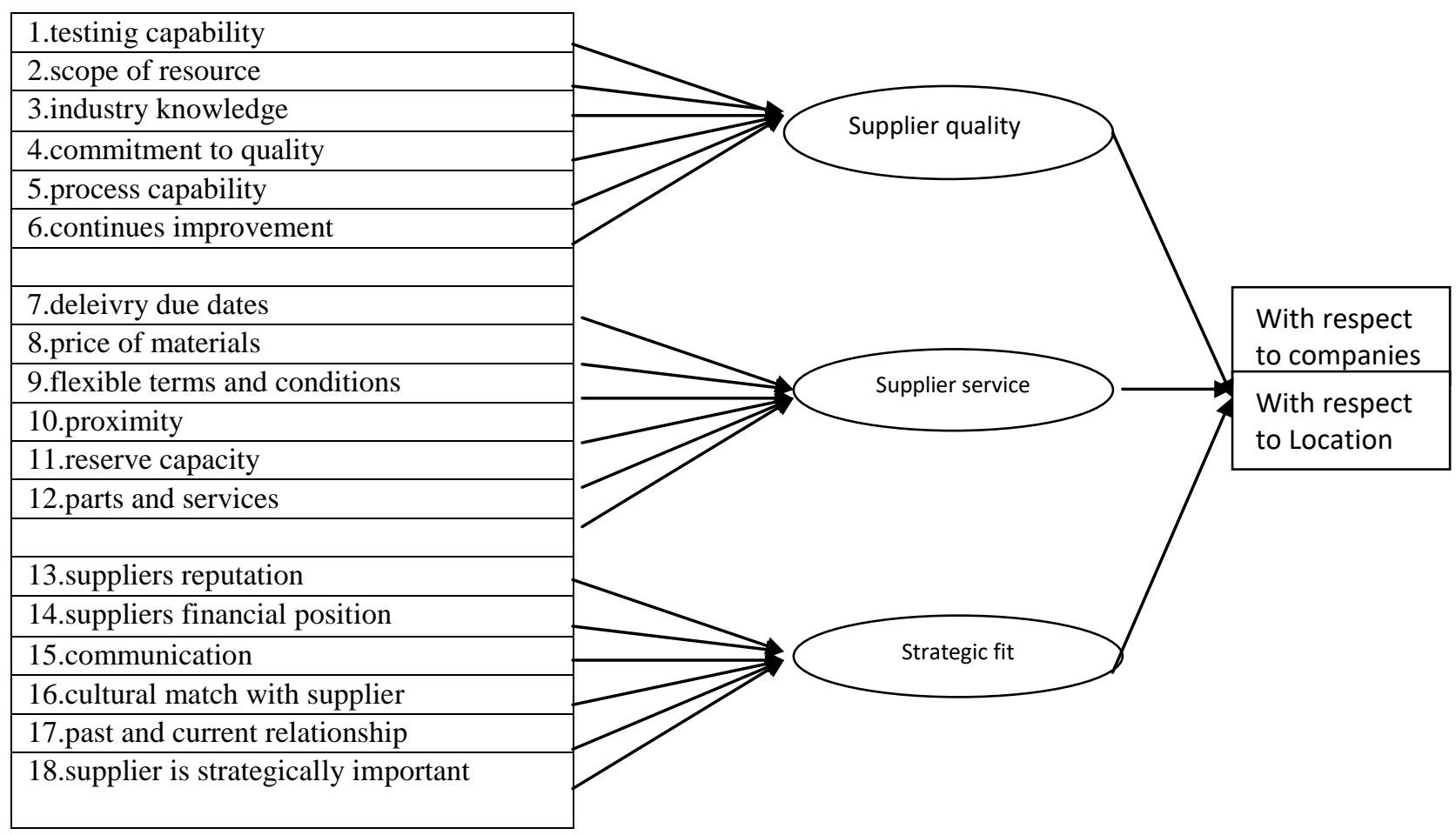




\section{Fig.1. Theoretical framework}

\section{Data Analysis}

\section{AHP (Analytical Hierarchy Process)}

An analytical hierarchical process (AHP) is developed to achieve the study's goals. AHP is a method of multi-criteria decision making (MCDM). MCDM is a well-known decision-making method that was developed by Saaty (1980). The fundamental goal of AHP is to categorize a set of options (for example, factors for supplier selection criteria) using a set of quantitative criteria and pair-wise comparisons provided by different decision makers. AHP produces a hierarchical leveling of factors for supplier selection criteria, with the upper level of hierarchy displaying the decision process's goal, the next level describing the selection criteria, which can be further subdivided into sub criteria at a lower level of hierarchy, and the bottom level of hierarchy displaying the alternative decisions to be evaluated.

\section{Overall Bike industries}

AHP is applied in order to categories the factors which affects the supplier selection criteria for overall motorbike industry. The results of AHP are given in table 4.1

Table 4.1: Global Weights for the Factors of Supplier Selection Criteria

\begin{tabular}{|c|c|c|c|c|}
\hline \multirow{2}{*}{ 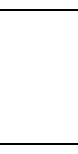 } & \multirow{2}{*}{ Factors } & \multirow{2}{*}{$\begin{array}{l}\text { GW } \\
\text { Overall }\end{array}$} & \multirow{2}{*}{$\begin{array}{l}\text { GW } \\
\text { Japanese } \\
\text { Companies }\end{array}$} & \multirow{2}{*}{$\begin{array}{l}\mathrm{GW} \\
\text { Chinese } \\
\text { Companies }\end{array}$} \\
\hline & & & & \\
\hline 1 & $\begin{array}{l}\text { Commitment to continuous improvement in product and } \\
\text { process. }\end{array}$ & 0.31023 & 0.239964 & 0.365712 \\
\hline 2 & Testing capability. & 0.298834 & 0.135675 & 0.343215 \\
\hline 3 & Honest and frequent communications & 0.149143 & 0.239964 & 0.032864 \\
\hline 4 & Geographical compatibility/proximity. & 0.0717 & 0.239964 & 0.071784 \\
\hline 5 & Cultural match between the companies & 0.046771 & 0.03866 & 0.046272 \\
\hline 6 & Past and current relationship with supplier. & 0.03628 & 0.034508 & 0.04267 \\
\hline 7 & Supplier's willingness to share confidential information & 0.030643 & 0.010183 & 0.043939 \\
\hline 8 & Ability to meet delivery due dates & 0.023094 & 0.028196 & 0.21723 \\
\hline 9 & Flexible contract terms and conditions & 0.023094 & 0.009346 & 0.245401 \\
\hline 10 & Supplier has strategic importance to your firm & 0.008296 & 0.020168 & 0.053502 \\
\hline 11 & $\begin{array}{l}\text { Reserve capacity or the ability to respond to unexpected } \\
\text { demand. }\end{array}$ & 0.002156 & 0.003372 & 0.019316 \\
\hline
\end{tabular}

The results in table 4.1 show that the most important factor in supplier selection is commitment to continuous improvement in product and process (global priority weight $=0.31023$ ) followed by the testing capabilities (global priority weight $=0.2988$ ), Honest and frequent communications (global priority weight $=0.1491)$, Geographical compatibility $($ global priority weight $=0.0717$ ), cultural match between the companies (global priority weight $=0.0467$ ) etc. And the least important factor is reserve capacity or the ability to respond to unexpected demand (global priority weight $=0.002156$ )

From the above table we can analyze that commitment to continuous improvement in the product and processes is the major contributor in selection criteria for supplier selection. It means that in Pakistan companies are selecting those suppliers who are committed in making continuous improvements in the product and processes this is due to the fact that bike industry of Pakistan is not having good quality and performance so that is why they are showing continuous improvements in their operations.

For the overall motorcycle industry AHP tool indicates that testing capability is the second 
important factor in supplier selection process. Companies are heavily trusting on the innovated suppliers to make competitive advantage on other motorcycle manufacturing companies. They all are also focusing on in continuous improvements in their products and processes. As authors of many articles says that companies are making strategies to cut down their costs and making improvements in their production so that they become efficient and effective. This table also indicates that reserve capacity is the least important factor in supplier selection. Because in Pakistan companies are having similar kind of demand with almost same growth rate so they can easily predict the demands of the motorcycles.

\section{Japanese Companies}

For the Japanese motorcycle brands AHP indicates that Commitment to continuous improvement in product and process, Geographical compatibility/proximity, Honest and frequent communications are having same global weights of 0.239964 , it means to improve your products and processes companies should select those supplier who are located near to them so that they can bring transparency in their communication. When they will have transparency in their communication then they will be able to improve their product and processes.

\section{Chinese Companies}

As far as Chinese bikes brands are concerned above table indicates that they are selecting those suppliers who are committed to in making continuous improvements in the product and processes this is due to the fact that Chinese bikes are not having good quality and performance so that is why they are showing continuous improvements in their operations. They are having reserve capacity as a least important factor because already they are producing is enough to meet their current demands.

Second important factor is testing capability as the most important factor. Chinese bikes are bringing innovation in their brands by offering new bikes style in different colors and sizes as Qinqui they have recently launched 200 cc motorcycle.

Lastly they have reserve capacity and this is because of they are having stagnant demands and sales flows.

For the overall motorcycle industry of Pakistan Service and quality is having mean weight of 1.5863 which shows that it lies in the acceptance region of supplier selection process in comparison Trust and Convenience and strategic management fit are having greater mean. So we can say that service and quality is the most important factor and companies prefer to select those suppliers who are bringing innovation in their product, who are making good long term relationship with companies and those who are ready to share confidential information with the companies in supplier selection process of Pakistan.

As far as Chinese and Japanese motorbike companies are concerned they also give preference to service and quality factor. In comparison of these two brands Japanese companies are making more efforts towards service and quality factor with the mean of 1.52 and Chinese companies in contrast are putting less effort with the mean of 1.59 but Chinese companies are also making improvements in their products quality and features the difference between these two is very small. Strategic management fit is also lies in neutral region but it is the least important factor in supplier selection process 
Table 4.2: Weighted Indices of Supplier Selection Criteria

\begin{tabular}{|c|c|c|c|c|c|c|c|}
\hline \multicolumn{8}{|c|}{ Weighted indices of supplier selection criteria } \\
\hline \multirow[b]{2}{*}{ Factor Name } & \multicolumn{2}{|c|}{ Motorbike OA } & \multicolumn{2}{|l|}{ Chinese } & \multicolumn{2}{|l|}{ Japan } & \multirow[t]{2}{*}{$\mathrm{p}$} \\
\hline & $\mathrm{N}$ Mean & S.D. & N Mean & S.D & N Mean & S.D. & \\
\hline TAC & 242.3324 & 1.43625 & 212.3857 & 1.51091 & 31.9589 & .809160 .54 & 0.65 \\
\hline SAQ & 241.5863 & .35800 & 211.5944 & .37108 & 31.5291 & .302072 .12 & 0.04 \\
\hline SMF & 242.5158 & .93281 & 212.4100 & .94198 & 33.2570 & .437660 .34 & 0.73 \\
\hline OSSI & 242.1448 & .59948 & 212.1300 & 63337 & 32.2483 & 320760.36 & 0.74 \\
\hline $\mathrm{N}$ & 24 & & 21 & & 3 & & \\
\hline
\end{tabular}

(TAC-Trust and Convenience, SAQ-Service and Quality, SMF- Strategic Management Fit, OSSOverall supplier selection)

Based on the data of table 4.2 we test the following hypothesis with independent $t$ test.

There are significant differences in supplier selection criteria among different companies

Independent sample $\mathrm{T}$ test indicates that Japanese and Chinese companies differ only with respect to service and quality factor. The descriptive statistics table indicates that Japanese companies are more of service and quality conscious in selecting their suppliers as compared to Chinese companies. However Chinese and Japanese companies were found to behave similarly towards strategic management fit factor and trust and convenience factor.

There is no difference between the factors "trust and convenience" but difference lies in the other two factors "strategic Management fit" and "Service and Quality". All four companies i.e. Suzuki, Honda, Yamaha, and China based companies are indifferent towards trust and convenience factor as evident in descriptive table. Yamaha and Chinese bikes are more concerned towards strategic and management importance of suppliers. Whereas, Suzuki and Honda are lesser inclined towards consideration of strategic and management fit as a supplier selection criteria. Lastly Yamaha, Suzuki and Honda regard service and quality as an evidential criterion for supplier selection but Chinese bike companies regard service and quality as less important indicator in selection of suppliers.

Overall supplier selection index given in table 4.3 is positively and significantly correlated with trust and convenience and service and quality factor. Hence, more importance of these two factors should be given in the final selection of suppliers. Above table explained that in overall supplier selection criteria of Pakistan Service and quality is the most important factor in supplier selection as if we improve service and quality factor then trust and convenience factor will automatically get improvements. This is due to the fact when a supplier offers a good quality product to the company, the trust of the company will automatically get high they don't need to analyze that particular supplier again in this transaction the confidence of the supplier and company will increased. That is why service and quality plays a vital role in supplier selection process and it is also the major contributor in supplier selection.

As far as Trust and convenience factor is concern it the second highest contributor in supplier selection process if we improve this factor this will lead to improve the service and quality factor. This is due to the fact when a supplier offers a product which is continuously improving its quality and having located near to the company will again win the trust of the company. Strategic management fit is the least important factor in supplier selection process (Table 3). We also computed these correlation coefficients separately for the Japanese and Chinese companies 
Overall supplier selection index is positively and significantly correlated with trust and convenience and service and quality factor. Thus, thrusting the importance of these two factors in final selection of suppliers among Chinese companies. Table 3 explained that in Chinese bike industry Trust and Convenience factor is having maximum contribution which is having value 0.841. If they will improve their Service and quality factor it will also improve their trust and convenience factor too because these two factors are having significant relationship with each other.

Japanese bike companies have different preferences and criteria's for supplier selection. For them trust and convenience is most important factor in selection of suppliers. Service and quality is negatively correlated with trust and convenience factor implying that these companies don't consider service and quality as part of their strategic propositions and vice versa. In Japanese companies trust and convenience is having negative relationship but these companies are having positive relationship in between trust and convenience and strategic management fit. This is due the fact these Japanese companies are giving strategic importance to their suppliers.

Table 4.3: Correlations Overall motor Bike Industry

\begin{tabular}{lllll}
\hline Variables & $\begin{array}{l}\text { TAC weightedSMF } \\
\text { index }\end{array}$ & $\begin{array}{l}\text { Weighted } \\
\text { index }\end{array}$ & $\begin{array}{l}\text { SAQ } \\
\text { weighted } \\
\text { index }\end{array}$ & $\begin{array}{l}\text { OSSI } \\
\text { index }\end{array}$ \\
\hline TAC weighted index & 1 & .063 & .075 & $.850^{* *}$ \\
SMF weighted index & 1 & -.139 & .178 \\
SAQ weighted index & $.137^{*}$ & 1 & $.551^{* *}$ \\
OSSI index & & & 1
\end{tabular}

**. Correlation is significant at the 0.01 level (2-tailed).

Research question 2: Do supplier selection criteria differ with respect to different regions?

Significant differences were found among purchasers belonging to different areas of Pakistan towards supplier selection criteria of trust and convenience (table 4.4 and table 4.5)

Table 4.4: Descriptive

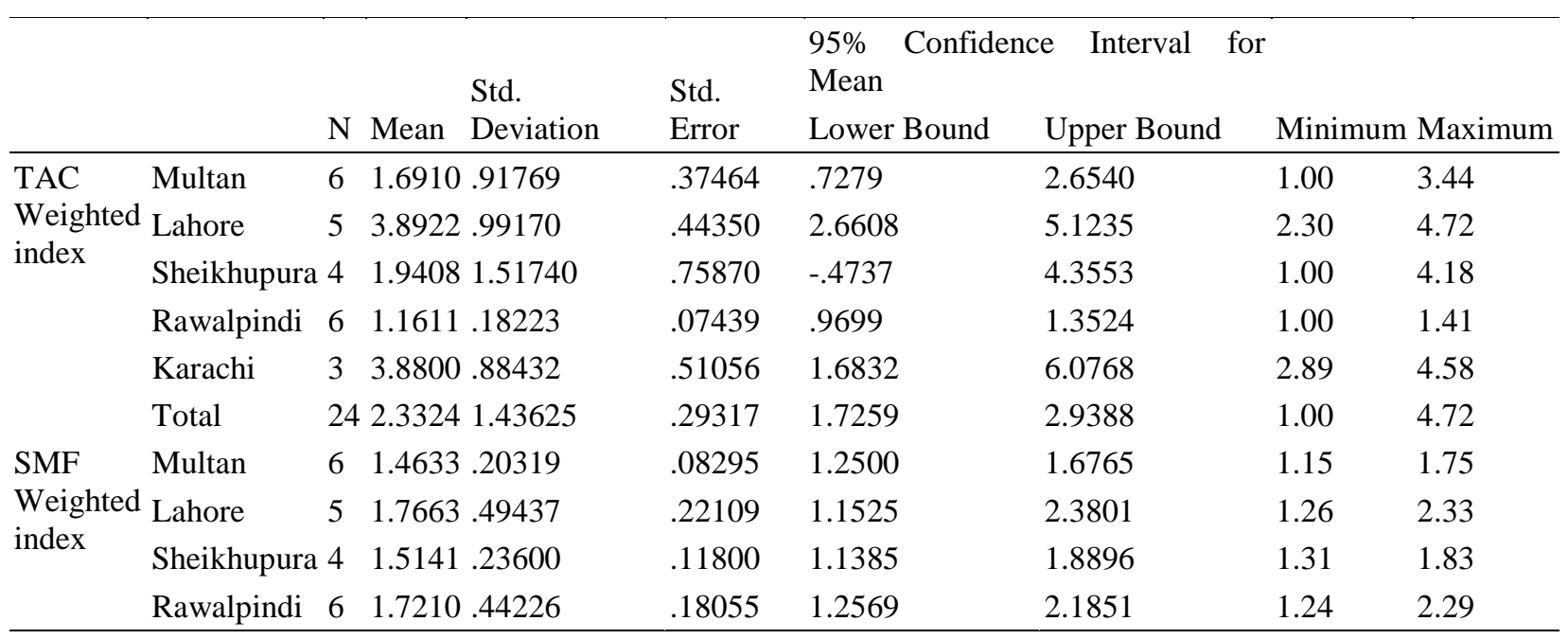




\begin{tabular}{|c|c|c|c|c|c|c|c|}
\hline \multirow{5}{*}{$\begin{array}{l}\text { SAQ } \\
\text { Weighted } \\
\text { index }\end{array}$} & Karachi & $\begin{array}{ll}3 & 1.3590 .20136\end{array}$ & .11626 & .8588 & 1.8592 & 1.22 & 1.59 \\
\hline & Total & 241.5863 .35800 & .07308 & 1.4351 & 1.7374 & 1.15 & 2.33 \\
\hline & Multan & $\begin{array}{ll}6 & 2.42361 .13739\end{array}$ & .46434 & 1.2300 & 3.6172 & 1.15 & 4.00 \\
\hline & Lahore & $\begin{array}{ll}5 & 2.9924 .51449\end{array}$ & .23009 & 2.3536 & 3.6312 & 2.29 & 3.55 \\
\hline & Sheikhupura & $4 \quad 3.0732 .34644$ & .17322 & 2.5220 & 3.6245 & 2.89 & 3.59 \\
\hline \multirow{9}{*}{$\begin{array}{l}\text { OSSI } \\
\text { index }\end{array}$} & Rawalpindi & $\begin{array}{ll}6 & 1.9064 .96182\end{array}$ & .39266 & .8970 & 2.9157 & 1.04 & 3.15 \\
\hline & Karachi & $3 \quad 2.38201 .18081$ & .68174 & -.5513 & 5.3153 & 1.59 & 3.74 \\
\hline & Total & 242.5158 .93281 & .19041 & 2.1220 & 2.9097 & 1.04 & 4.00 \\
\hline & Multan & $\begin{array}{lll}6 & 1.8593 .37456\end{array}$ & .15291 & 1.4662 & 2.2523 & 1.29 & 2.26 \\
\hline & Lahore & $\begin{array}{ll}5 & 2.8836 .41612\end{array}$ & .18610 & 2.3669 & 3.4003 & 2.21 & 3.30 \\
\hline & Sheikhupura & $4 \quad 2.1760 .45718$ & .22859 & 1.4486 & 2.9035 & 1.74 & 2.82 \\
\hline & Rawalpindi & $\begin{array}{lll}6 & 1.5962 .38031\end{array}$ & .15526 & 1.1971 & 1.9953 & 1.09 & 2.03 \\
\hline & Karachi & $\begin{array}{ll}3 & 2.5403 .10883\end{array}$ & .06284 & 2.2700 & 2.8107 & 2.42 & 2.62 \\
\hline & Total & 242.1448 .59948 & .12237 & 1.8917 & 2.3980 & 1.09 & 3.30 \\
\hline
\end{tabular}

Table 4.5

Table 5 ANOVA

\begin{tabular}{lllllll}
\hline & & $\begin{array}{l}\text { Sum } \\
\text { of Squares }\end{array}$ & df & Mean Square & F & Sig. \\
\hline TAC & Between Groups & 30.663 & 4 & 7.666 & 8.679 & .000 \\
weighted & Within Groups & 16.782 & 19 & .883 & & \\
index & Total & 47.445 & 23 & & & \\
SMF & Between Groups & .538 & 4 & .134 & 1.060 & .403 \\
weighted & Within Groups & 2.410 & 19 & .127 & & \\
index & Total & 2.948 & 23 & & & \\
SAQ & Between Groups & 4.712 & 4 & 1.178 & 1.463 & .253 \\
Weighted & Within Groups & 15.301 & 19 & .805 & & \\
index & Total & 20.013 & 23 & & & \\
OSSI & Between Groups & 5.498 & 4 & 1.374 & 9.434 & .000 \\
index & Within Groups & 2.768 & 19 & .146 & & \\
& Total & 8.266 & 23 & & & \\
\hline
\end{tabular}

Based on the results of table 4.4 and table 4.5 , we see that there are significant differences among selection orientation of purchasers belonging to Lahore and Karachi. While no significant differences were found in supplier selection criteria of service and quality and strategic and management fit among purchasers belonging to different areas of Pakistan. Multan, Rawalpindi and sheikhupura purchasers consider Trust and Convenience as an utmost important in selecting suppliers. On the other hand Karachi and Lahore's purchasers gave least consideration to trust and convenience factor in supplier selection. Purchasers residing in all five cities they have similar tendency towards service and quality and strategic management fit as criteria of supplier selection. Purchasers in all five cities consider service and quality and strategic management fit as formidable and reliable criteria for supplier selection. Now the question arises that why purchasers of Lahore and Karachi give least importance to Trust and Convenience? This is due to the matter of fact that there are a lot of manufactures are working in Lahore and Karachi. Suppliers are working near to them that are why geographical compatibility and frequent communications are not important variables for them. Due to close proximities of suppliers and purchasers the element of trust is restored. So it doesn't become a major criterion in these two cities 


\section{Conclusion}

In Pakistan supplier selection is having great importance but they are lacking in making long term relation with their suppliers and not considering their supplier a strategic business partners. But in this competitive business environment you have to made a responsive supply chain and in least possible cost so in this process selection of appropriate supplier plays a vital role in maintaining relationship and matching needs of the buyer.

The purchaser should consider that he should provide such environment for their supplier to add value in their business transactions. From above all we can conclude that traditional supplier selection on the basis of quality and services are important but there is a great need to create strategic relationship in between supplier and buyer supplier should consider their supplier in obtaining goals and objectives of the company so that they feel their importance in companies performance.

This research has highlighted the importance of supplier selection in Pakistan and showed that Pakistani purchasers are still working with traditional supplier selection process they only consider supplier quality, and want transparency in communication and continuous improvement in product services and processes. This common practice was found in each and every corner of the world.

The significance of supplier selection variables in the Pakistani motorcycle industry is demonstrated in this study. Continuous improvement, geographical proximity and compatibility, and the ability to meet delivery deadlines, as well as the ability to communicate honestly and frequently with suppliers, are all factors to consider. Companies' willingness to have a strategic partner rather than a supplier in their supply chains has increased as market competition has increased. This factor demonstrates that Pakistani automakers do not want to develop long-term relationships with their suppliers by forming closer bonds and sharing confidential information.

Because these automotive companies provide more important technical expertise level, financial stability, and honest communication, selecting the most appropriate suppliers is considered an important strategic Management decision that affects all areas of an organization. Because they want to form strategic alliances with the best supplier, companies place a premium on quality and price.

\section{Recommendations}

Pakistani motorcycle industry is heavily depending in importing their products to assemble the bikes so appropriate supplier selection is becoming very important for the manufacturers. Companies are looking for those suppliers who provide them their desired products in least possible cost and maximize their profitability. In Pakistan purchasers are more concerned with the quality and cost of the product, they are not focusing on making strategic long term relations with their suppliers so the element of making relationship with the supplier is very important.

Quality is also an important factor in selecting the supplier and it should not be for cost in the selection of the supplier.

Due to technological advancements and short product life cycles customers are expecting new design and modern technologies in the bikes so purchaser should consider the element of innovation while selecting the supplier to match the customer demand.

Companies should consider those suppliers, having strategic importance to their firm so they should built consensus between the company and the supplier that every decision will be made through mutual collaboration. Companies should make relationship with their suppliers and try to make transparency in business transactions. 


\section{References}

Aissaoui, N., Haouari, M., \& Hassini, E. (2007). Supplier selection and order lot sizing modeling: A review. Computers \& operations research, 34(12), 3516-3540.

Chan, F. T., \& Chan, H. K. (2004). Development of the supplier selection model a case study in the advanced technology industry. Proceedings of the Institution of Mechanical Engineers, Part B: Journal of Engineering Manufacture, 218(12), 1807-1824.

Chin-Chun Hsu, Vijay R. Kannan, G. Keong Leong and Keah-Choon Tan (2005), "Supplier selection construct: instrument development and validation". The International Journal of Logistics Management Vol. 17 No. 2, 2006 pp. 213-239

Das, S. K., \& Abdel-Malek, L. (2003). Modeling the flexibility of order quantities and lead-times in supply chains. International journal of production Economics, 85(2), 171-181.

GÜRLER, A. G. İ. (2007). Supplier selection criteria of Turkish automotive industry. Journal of Yaşar University, 2(6), 555-569.

Kannan, V. R., \& Tan, K. C. (2003). Attitudes of US and European managers to supplier selection and assessment and implications for business performance. Benchmarking: An International Journal, 10(5), 472-489.

Kannan, V. R., \& Tan, K. C. (2004) "Supplier selection and assessment : And their impact on business performance" The Journal of Supply Chain Management: A Global Review of Purchasing and Supply Copyright (C) November2005, by the Institute for Supply Management, Inc

Kannan, V. R., \& Tan, K. C. (2004). Supplier alliances: differences in attitudes to supplier and quality management of adopters and non-adopters. Supply Chain Management: An International Journal, 9(4), 279-286.

Kannan, V. R., \& Tan, K. C. (2006). Buyer-Supplier Relationships: The Impact of Supplier Selection and Buyer-Supplier Engagement on Relationship and Firm Performance. International Journal of Physical Distribution \& Logistics Management, 36(10), 755-775.

Julie, J. G. (1996). Carrier involvement in buyer-supplier strategic partnerships. Logistics Information Management, 9(6), 54-61.

Park, S., Hartley, J. L., \& Wilson, D. (2001). Quality management practices and their relationship to buyer's supplier ratings: a study in the Korean automotive industry. Journal of Operations Management, 19(6), 695-712.

Peter R. Davis (2007) A relationship approach to construction supply chains. Industrial Management \& Data System, 108(3),310-327.

Saaty, L; (1980) The Analytic Hierarchy Process. McGraw-Hill, New York.

Sarkis, J., \& Talluri, S. (2002). A model for strategic supplier selection. Journal of supply chain management, 38(4), 18-28.

Sonmez, M. (2006). Review and critique of supplier selection process and practices. (C) Loughborough University. 